\title{
The Gendering of Context: A Fresh Perspective of Women Social Enterprise in Pakistan
}

\author{
Mohammad Sohail Yunis ${ }^{1}$, Hina Hashim² ${ }^{2}$ Sajida $^{3}$
}

\begin{abstract}
Entrepreneurship has been anticipated as a male "gendered connotation" and is considered a "masculine concept". There is very limited academic work pertaining to women entrepreneurship and social entrepreneurship in the context of developing countries. Our research theoretically contests the explicit masculinist traditional entrepreneurship perspective and aims to investigate the drivers and hurdles of women social entrepreneurship in a developing country context (Peshawar, Pakistan). This research integrates and capitalizes on a theoretical lens grounded in "new institutional theory" and "feminism perspectives". Hence, this research contributes by emerging a useful multilayer theoretical logic through integration of the two competing theoretical perspectives and adds new insights to entrepreneurship theory and practice. We argue that women's entrepreneurial choices revolve around and are shaped by a complex interplay between socio cultural contexts. Capitalising on an interpretive, exploratory and qualitative research methodology, we have collected empirical data through semi structured in-depth interviews from ten women social entrepreneurs of Peshawar, KP, Pakistan and analysed and presented through qualitative thematic analysis. Empirically, this paper identifies how women entrepreneurs exercise agency to negotiate their roles within the household and the society and debates on various interesting perspectives that relates to the women entrepreneurship such as "women empowerment, patriarchal culture, religious extremism and terrorism, change creators, institutional corruption and security issues". The paper also provides insights on how gendering of context determines social entrepreneurship in KP, Pakistan.
\end{abstract}

Key Words: Gender, context, social entrepreneurship, institutional theory, feminist theory

\section{Introduction}

Women around the world are effectively contributing to different sectors (such as government, civil, bureaucracy, business and politics) and their role is certainly getting reformed. As the western world is recognizing the contribution of their women

1 Assistant Professor, Institute of Management Sciences, Peshawar. Email: sohail.younis@imsciences.edu.pk

2 Swedish University of Agricultural Sciences. Email: hina.hashim@slu.se

3 Institute of Management Sciences. Email: sajida_tayyeb@hotmail.com

\section{ARTICLE HISTORY}

29 May, 2019 Submission Received

01 Jul, 2019 First Review

17 Oct, 2019 Second Review

10 Feb, 2020 Third Review

03 Mar, 2020 Accepted 
and consider them on more equal footing with men, Pakistani women still struggle to celebrate their achievements. Pakistan is ranked as the sixth most populated country around the globe, with an approximately 50 percent women population (Bukhari, Gaho \& Soomro, 2019). However, it also highlights women dealing with numerous challenges including dynamic shift, legacy and conviction (Yunis, Hashim \& Anderson, 2019). Women are not offered similar opportunities like men. Here, women are usually referred as "makers of a home". They are expected to lay low and withhold participation in business activities. However, there is still a certain segment of women in urban Pakistan, striving for social independence through entrepreneurship (see for example Bukhari et al., 2019; Roomi \& Parrott, 2008; Yunis et al., 2019). The entrepreneurial participation of women in Pakistani has been debatable and lately enticed the attention in the research and literature (Roomi, Rehman \& Henry, 2018). It has been argued that women face "discrimination" and "gender inequality" owing to gender biased power relations (Yunis et al., 2019). In Pakistani, women subordination prevails through gender norms and culture that lead to the society holding diverse and contradictory views about the definition of "women rights" (Roomi \& Harrison, 2010; Yunis et al., 2019). Therefore, this study examines and specifies the need to associate entrepreneurship practices with relevant theories (institutional and gender) in the context of Pakistan. Our research questions focuses on the impact of gendered institutions on entrepreneurship process. After referring to relevant literature, we present an exploratory study, documenting drivers and barriers of women social entrepreneurs of Peshawar, KP Pakistan. In addressing this research question, this research looks into the entrepreneurial process with a contextual gendered lens and highlights the factors that enable and constrain the entrepreneurs, through explanatory power of institutional and feminist theories. Furthermore, our research offers interesting insights into women entrepreneurship in the context of a developing country and contributes to the relevant literature.

Traditionally, academic research and literature on women entrepreneurship (both in developing and developed countries) primarily focus on the personal attribute and ignores the context. Most of the previous research focused on the characteristics of women entrepreneurs, presented their profile, highlighted their background and showed their experiences. Such perspectives show gender as a variable approach with women entrepreneurs singled out and compared to their male colleagues (Brush \& Vanderwerf, 1992). However, recently, the entrepreneurship research has noted a shift and started focusing on the feminist perspectives (Henry, Foss, Fayolle, Walker, $\&$ Duffy, 2015). Thus, our research has integrated "gender" in the "context" to understand women entrepreneurship.

On the basis of above arguments, we aim to understand that how the institutions 
context and gender dynamics play out in shaping women entrepreneurship practices in a complex environment (such as Khyber Pakhtunkhwa, Pakistan). To achieve this objective, we provide an insight into the contemporary literature on women entrepreneurship, followed by a critical discussion on institutional and feminist theory. This would help us to develop our conceptual framework to analyze empirical data.

\section{Women Entrepreneurship}

During the last few decades, women social entrepreneurship has caught noticeable consideration (Lent, Anderson, Yunis \& Hashim, 2019). It is a growing and emerging phenomenon (Zahra \& Wright, 2016), contributes in economic development by creating jobs (McMullen \& Warnick, 2015) and improves standard of life (Welter $\&$ Smallbone, 2011). Women entrepreneurship is also perceived as a determinant of entrepreneurship diversification in any given economic context. Nevertheless, an increased attention towards women entrepreneurial activities and its benefits, their expertise and skills remain unutilized in underdeveloped countries (like Pakistan) because of the economic and socio-cultural obstacles (Anderson, Yunis, Hashim \& Air, 2019).

In developing countries, women social entrepreneurs are increased significantly but their number is lower than men (Panda, 2018). Previous gender studies has mostly focused on exploring the distinctive micro or macro level characters of women social entrepreneurship such as personal traits, drivers, experience, financial access, performance, issues of success, decision models, perceptions, or the size of the firm (Baughn, Chua \& Neupert, 2006; Parvin, Rahman, \& Jia, 2012). Considering entrepreneurs in isolation and not as a particular context, presents a finite knowledge of entrepreneurship (Anderson et al., 2019). It is not only the entrepreneur who is gendered but socio-cultural contexts in which entrepreneurs work is also gendered (Al- Dajani, Carter, Shaw \& Marlow, 2015). Interestingly, gender perspective does not dominate entrepreneurial research (Gimenez \& Calabro, 2017). Therefore, there is a need to shift the attention of researchers to emphasize on social construction of gender and entrepreneurship. As a result, it could provide new apprehension in the theory and viewpoint of entrepreneurship. Our main proposition is that understanding of gender in the specific context of entrepreneurship is essential. This can be accomplished by studying entrepreneurship within its context in relation to the gender biased gaps identified by literature overtime while theorizing (Henry, Foss \& Ahl, 2016; Stead, 2017).

\section{Feminist Theory}

Feminist theory provides an alternative way of theorizing phenomenon (Hurley, 
1999). Hanson (1992) defined feminism by arguing that feminism views world through monocle of gender, and not particularly women or feminine. Feminist studies highlights diversity in both gendered individuals rather than focusing on the importance of one. Therefore, the way someone perceives gender is important in the understanding of entrepreneurship research (Stead, 2017). Interestingly, women entrepreneurship studies that apply the theory of feminism usually tend to describe gender dissimilarities in connection with the way women entrepreneurs diverge from supposed male convention (Foss, Henry, Ahl \& Mikalsen, 2018). Theorizing feminist theory is all about social change based on the assumptions that gender is an essential pillar of the societal structure (Fine, 2017). Women have been historically underprivileged and feminist theory seeks to end this condition for women. It has been pointed out by several researchers that entrepreneurship and entrepreneur are male gendered concepts and have masculine connotations (until 1980s it was a standard in science). This view existed because entrepreneurs traditionally were men, but others argue that women entrepreneurs did existed but were not upfront about it in the start (Berg, 1997; Fine, 2017; Stead, 2017). Such foundational text (shaping the research field) show feminist deconstruction within the research field of entrepreneurship, thus adding up to the theories to the study about men (Fine, 2017). These texts were mainly concerned with the function of entrepreneurship in economy however the emerging image is somewhat different which is of a heroic self-made person (Ahl, 2006).

Feminism is also influenced by the context (Zahra \& Wright, 2016). Entrepreneurs being restrained and empowered in terms of the domain they operate has received acknowledgement in literature. Only understanding and reviewing entrepreneurs in isolation and in the absence of a relevant context provides limited understanding of entrepreneurship (Berg, 1997; Sambharya \& Musteen, 2014). Some researchers claim that gender is not always referred to entrepreneurs; in fact, it is also an influential aspect in the case of socio-cultural context within which entrepreneurs operate (Berg, 1997; Knight, 2016). The surroundings in which entrepreneurship occurs is also subject to gender. These studies attempt to raise issues to be discussed about entrepreneurship theory and research and aim to valorize women entrepreneurship experience. As feminist theory is usually associated with women entrepreneurship, literature shows a prominent impact of gender positions in the institutional context in which women work. Therefore, merging institutional and feminism theories help in better understanding the influence of institutions on women entrepreneurship (Gimenez \& Calabro, 2017). Our above argument and discussion could be highlighted in the following figure 1.

\section{Institutional Theory}

Institutional theory is being utilized as a powerful theoretical lens for many en- 


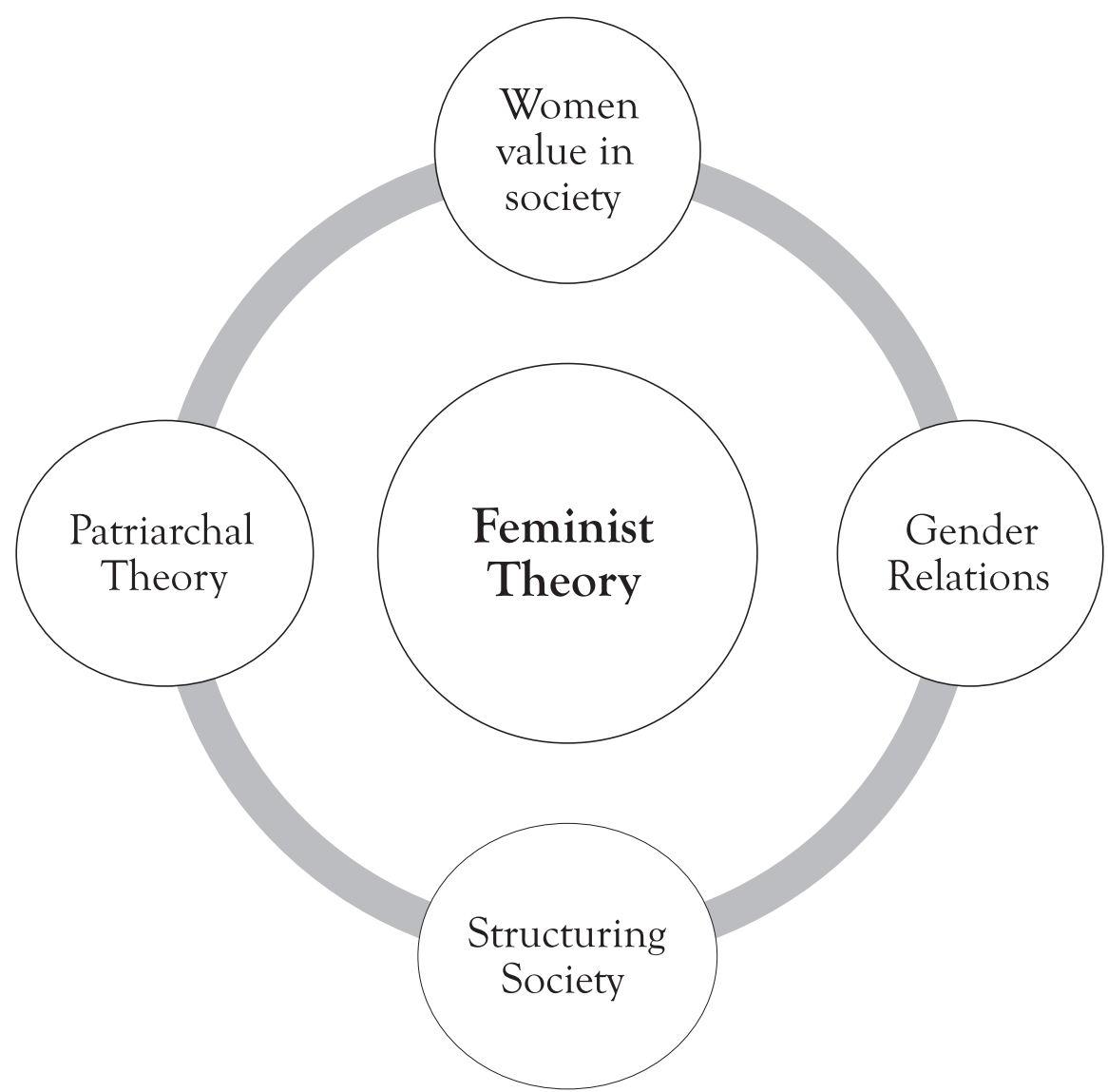

Figure 1: Feminism and Context, Adapted (Berg, 1997; Knight, 2016, Sambharya \& Musteen, 2014; Stead, 2017)

trepreneurial researches (Bruton, Ahlstrom \& Li 2010; Gimenez \& Calabro, 2017; Yunis et al., 2019). While women entrepreneurship is currently at a growing pace, literature on women entrepreneurship and institution theory still lack extensively and depth (Gimenez \& Calabro, 2017). North (1990) defined it as "the rules of the game in a society" (p.3). In recent times, institutional theory has advanced massively. The new perspective of institutional theory suggests that diverse cultural rules cause the organizations to rationalize and adopt the new rules (Scott, 2008). Furthermore, these rules are adopted without questioning. These rules can be formal or informal. The formal rules are mandatory and if organizations refuse to abide those, they can face formal sanctions. These formal institutions provide the regulatory frame while the informal rules are for informal institutions that are created outside of official sanctioned channels (Ettl \& Welter, 2010). Similarly, norms, culture and gender are explicit from informal organizations that carry religious and traditional values. These 
rules create status of women within a society (Scott, 2008; Ettl \& Welter, 2010). Noncooperation towards informal institutional rules may deliver an unfavorable reputation and affect their acceptance in society. It can even cause violent retaliation (Amable, 2003). Important feature of institutional theory is that it focuses in cognitive-cultural aspects of institutions and the role of embedding the shared meaning. This theory is a departure from strict interpretations of organizations to the kind that accommodates and respects cultural norms and values (Mason, Kirkbride \& Bryde, 2007). We argue that the roles that are ascribed to men and women are the result of manifesting gender in cultural norms, traditions and religion (informal institutions). This manifestation

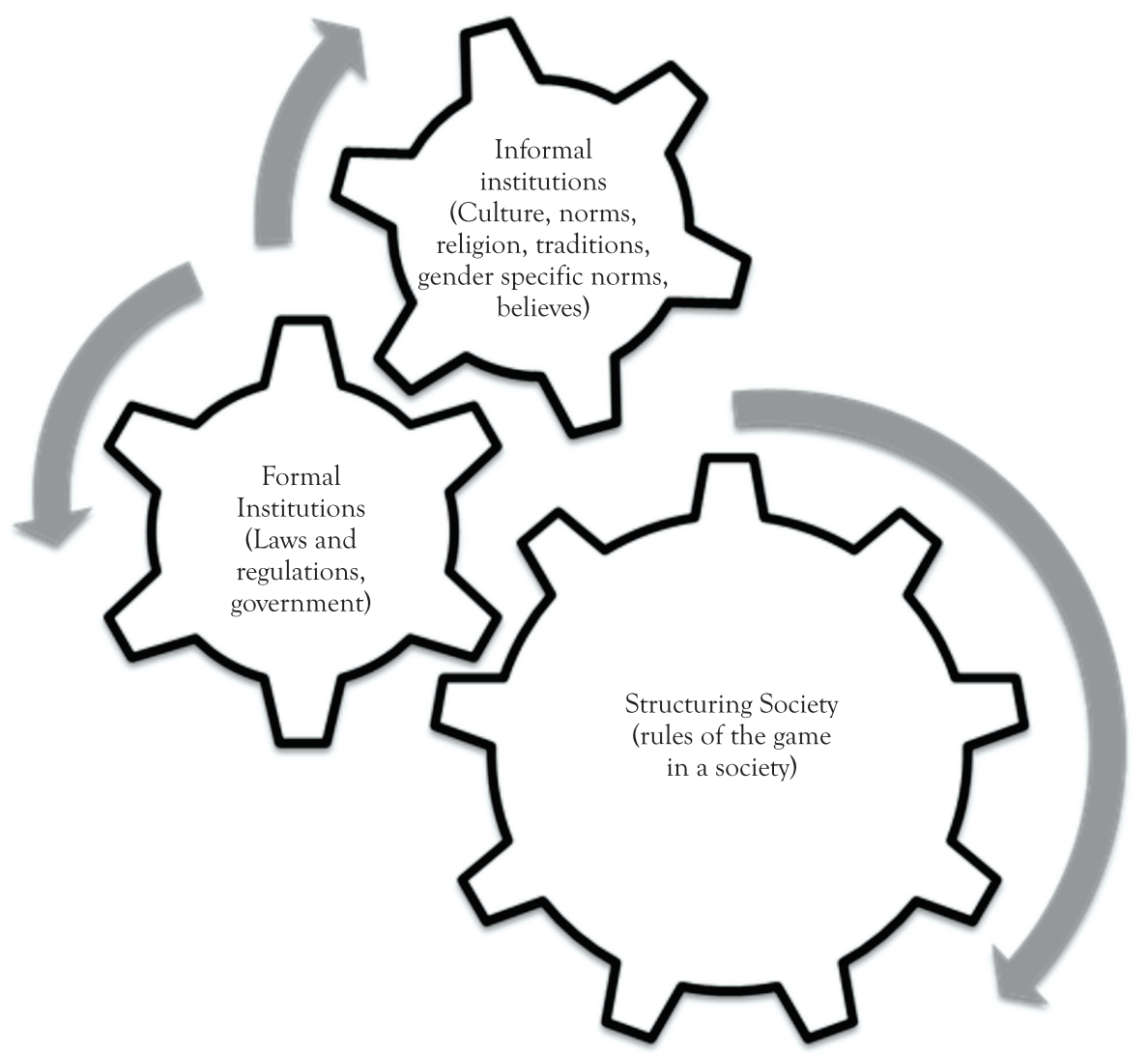

Figure 2: Institutions and Context, Adapted (Scott, 2008; Ettl \& Welter 2010; Bruton et al., 2010; Gimenez \& Calabro, 2017; Yunis et al., 2019)

can influence the routes, extent, form and even success of women social entrepreneurs (Ettl \& Welter, 2010). Our argument regarding institutions is presented in figure 2. 


\section{Background Information about KP, Pakistan and Status of Women}

Pakistan is one of the South Asian countries with a current Muslim population of 96.4 per cent. Nearly half of its population, 49.2 per cent consists of women. Moreover, 15.42 per cent of Pakistan's population is formed by Pakhtun society and they belong to KP province of Pakistan (Economic Advisor's Wing, 2016). Pakistan is an Islamic country and dominated by Islamic culture, customs, and norms. The traditional Pakistani women are supposed to be care takers of a home and carrier of family's dignity by staying within boundaries of the home. In Pakistan and many similar countries, social norms and traditional values are appreciated by the masses. The constitution of Pakistan is in accordance with Islamic teachings; however, its social setup is dominated by pre-Islamic ethnic values (Pakeeza, 2015). Consequently, they promote the culture of patriarchy to ensure women's structural subordination to men. The social system of Pakistan allows men to control women's life because masculinity forms one of the fundamental aspects of its society. Traditional roots and social beliefs collectively form the roles of gender in Pakistan (Zaman, Stewart \& Zaman, 2006). This is mainly dependent on the conception of producing and reproducing, as feminine and masculine characteristics of a person (Pakeeza, 2015). Social importance of gender is decided by the patriarchy system which is ingrained in the traditional and cultural formations of Pakistani civilization. As a result, women are restricted to domestic domain with the role of reproduction at hand; whereas, men are held to be bread earners in public domain (Zaman et al., 2006). Women in Pakistan are deprived of social value and position for invalidating their duty of producing and providing financially. Men are endowed with educational opportunities and skill-development to avail resources; whereas, women are bestowed interior and home-based skills to become domestically efficient. This approach is the main reason for women's economic and social dependence in Pakistan (Pakeeza, 2015). The abovementioned determinants are further supported by institutions in the country that are reined by institutional biasness towards gender.

\subsection{Position of women in Khyber Pakhtunkhwa (KP)}

$\mathrm{KP}$ is struggling with "Gender modernism" and it is now becoming a place where women are standing up for their rights and are showing resistance to gender biasness. However, the obstructionist behaviors still exists which slabs opportunities for many educated women leaving (Anderson et al., 2019). Within Pakhtun society, cognitive attributes of Islam hold great importance. These attributes distinguish social position and determine the level of one's involvement in religion of Pakhtun society. According to their perception, women battling for their rights, choosing a career, becoming financially sound or working in male environment are not acceptable and not aligned 
with their religious beliefs. These symbols have social significance in Pakhtun society. The trend is slowly shifting due to the illiberal religious bodies that are gender-biased and mainly demote women in domestic responsibilities (Pakeeza, 2015). Low literacy level, feminist culture, patriarchal approach, inaccessibility of information for women, lack of knowledge, and job in constrained environment are some of the challenges women face in Pakistan (Zaman et al., 2006). Therefore, they mostly stay at home and are not allowed to participate in decision-making processes.As KP's culture, norms, values are unique and different; therefore, they need to be understood in accordance with the environment to fully understand the mechanism for initiating prosperous women entrepreneurship.

\section{Theoretical and Conceptual Positioning}

We argue that an integrated theoretical lens of institutional and feminism theory is extremely useful in examining women social entrepreneurship in case of developing countries (KP, Pakistan in this case). It allows researchers to evaluate complexity of social and cultural context using an integrated version of institutional and feminism monocle. Similar to the recent studies about social entrepreneurship (Gimenez \& Calabro, 2017; Yunis et al., 2019) the researcher adopts a concept in which women entrepreneurship is structured in particular case. We seek to explore through qualitative analysis how societal structure influences women entrepreneurship in the KP Pakistan context and how that constraints or enables them. We tried to probe Scott's conception among formal and informal institutions that presents a proper understanding regarding the environment within which entrepreneurs operate (context). In addition to that it also regulates individual behavior of both men and women. Important feature of institutional theory is that it focuses in cognitive-cultural aspects of institutions and the role of embedding the shared meaning. This theory is a departure from strict interpretations of organizations to the kind, which accommodates and respects cultural norms and values (Mason et al., 2007). Informal institutions are composed of ground rules for an individual in a society to coordinate. These regulations also strengthen or dismay one's entrepreneurship conduct (Scott, 2008; Ettl \& Welter, 2010).It also affects and restricts an entrepreneur's values and practices because nonobservance to these regulations may result in unfavorable reputation and unacceptability in society (Amable, 2003). So in order to get communities approval, one needs to limit their actions and beliefs, thus resulting in emergence of social entrepreneurship. These informal forces shape the position of an entrepreneur in society. On the contrary, the regulative bodies deal with formal laws that are obligatory and if not followed may follow a formal penalty (Ettl \& Welter, 2010). Therefore, these regulative bodies manage to implement social entrepreneurship and also play important role in structuring society. While studying entrepreneurship, it is important 
to understand that one explores gendered situations in a gendered context. Many researchers (Bruton et al., 2010) acknowledge the fact that entrepreneurship is subject to restriction and requires validation by environment. Certain categorizations namely, male and women, context or domain, entrepreneur is important in understanding entrepreneurship activities. The case of KP, Pakistan is an example of a setup based on feminist patriarchy approach, which affects social construction of institutes in this area. Previously mentioned Fig. 1in this paper is constructed on this belief regarding theory of feminism. It suggests that the terrain of feminism presents a comprehensive framework that helps understand gender in a specific situation. Moreover, it also helps in explaining the way it associates with forming of society and entrepreneurship. Focusing on this viewpoint, the researcher attempted to comprehensively explore drivers and barriers of women social entrepreneurship in the context of a developing country. In addition, we argue that relevant institutional setting and feminism pressures are at play and structure the society in developing countries. Thus, considering these two perspectives together are integral part of this exploration.

\section{Methodology}

An interpretive qualitative research has been adopted by the researcher for this particular research. The process of data collection captured a span of 19 months being part of wider research program based on issues and challenges within KP, Pakistan. Purposive sampling method was used because it helps researcher view situations contrarily and choose such a sample case that relates to the parameters of the population that's being studied (Silverman, 2008). The researcher utilized on 10 in-depth interviews with successful women social entrepreneurs of KP, Pakistan. Similar, sample has been used in contemporary literatures (see for example Yunis, et al., 2019; Lent et al., 2019). The interview lasted for minimum 55 minutes, maximum 170 minutes. The gained information (from the interviewees) was then analyzed and combined with knowledge from previous researches. This resulted in consolidated model of Women social entrepreneurial issues, barriers and challenges.

\subsection{Structural and personal profile of interviewees}

The interviewees' businesses could be categorized into self-owned or managed micro and small enterprises. Majority of the businesses were related to traditional sector including fabric/clothing, educational, personal care services (salons), career trainings and food. Most of them (90\%) were concentrated in the service sector having women customers predominantly (Table 1). This attitude of women entrepreneurs of Peshawar, KP Pakistan is in line with the social norms of almost all other Islamic countries (McElwee \& Al-Riyami, 2003). They function in those sectors where minimum communication takes place between men and women (for instance, educational 
and food-based sectors) or sectors in which no requirements of interaction between male and women (health, personal care salons, career trainings).

Each interview was recorded on tape and then transcribed. A summary of each was then produced for thematic analysis. Each interview was analyzed in relation to the following levels;

Table 1: Profile of Interviewees

\begin{tabular}{|c|c|}
\hline $\begin{array}{c}\text { Female social entrepre- } \\
\text { neurs Interviewees }\end{array}$ & Business (product/service based) \\
\hline Mrs. A & $\begin{array}{c}\text { Products and services(fabrics, educational institutes, personal care } \\
\text { salons, career trainings and food-based business) }\end{array}$ \\
\hline Ms. B & Service Based (Beauty Salon) \\
\hline Ms. C & Service Based (Beauty Salon) \\
\hline Mrs. D & Services and Products(Fabrics/clothing, Career Schooling) \\
\hline Ms. E & Service and product Based (Textiles, Vocational trainings, education) \\
\hline Mrs. F & Service Based (Education) \\
\hline Ms. G & Services (Beauty Henna Artist) \\
\hline Mrs. H & Services(Organic food services) \\
\hline Ms. I & Services and Products (Online Business, career schooling, education- \\
& al) \\
\hline Mrs. J & Services (Educational) \\
\hline
\end{tabular}

1. The general background of the interviewee

2. The motivation to become a social entrepreneur

3. Barriers, Issues and challenges faced

\section{Analysis}

The data has been analyzed through thematic analysis (Attride-Stirling, 2001). Thematic analysis helps to compare various concepts and opinions of the previous researchers with the data collected. It is considered appropriate for studies that try to discover using interpretations that fits well with this study (Creswell, Hanson, Clark \& Morales, 2007). Thematic analysis involved specific steps as follows. 1. Getting fully familiar with the data thay has been collected through thorough reading, 2. Coding the material, 3. Identifying themes (Table 2) (Basic, organizing and Global), 4. Constructing the networks (Figure 1), 5. Describing and exploration of the thematic networks. 
Table 2: Themes from Interviews

\begin{tabular}{|c|c|c|}
\hline Codes from data & $\begin{array}{c}\text { Basic Themes driverd from } \\
\text { data }\end{array}$ & $\begin{array}{l}\text { Organizing Themes derived } \\
\text { from data }\end{array}$ \\
\hline HobbiesFriends & \multirow{10}{*}{$\begin{array}{l}\text { Significance of Individual Aims } \\
\text { and Risk-taking } \\
\text { Significance of Assistance and } \\
\text { Motivation from Close Family }\end{array}$} & \multirow{10}{*}{$\begin{array}{l}\text { Entrepreneurs'individual char- } \\
\text { acteristics and family assistance } \\
\text { lead to success }\end{array}$} \\
\hline Family & & \\
\hline Assistance & & \\
\hline Acknowledgement & & \\
\hline Motivation & & \\
\hline Non-acceptance & & \\
\hline Risk-taking & & \\
\hline Courageous & & \\
\hline Aims & & \\
\hline Aspiration & & \\
\hline Home Managers & \multirow{9}{*}{$\begin{array}{l}\text { Women perceived frail than } \\
\text { men } \\
\text { Out of home perceived inap- } \\
\text { propriate for women } \\
\text { Regligion's mistreatment }\end{array}$} & \multirow{9}{*}{$\begin{array}{l}\text { Gender imbalance - feminist } \\
\text { theory/institutional context }\end{array}$} \\
\hline Women being Frail & & \\
\hline $\begin{array}{c}\text { Making Money associated with } \\
\text { Men }\end{array}$ & & \\
\hline Prohibition in Islam & & \\
\hline Celibacy needed for Women & & \\
\hline Niqab for women & & \\
\hline $\begin{array}{c}\text { Appropriate limits among men } \\
\text { and women }\end{array}$ & & \\
\hline Safeguardingcelibacy & & \\
\hline Guardian of family's Integrity & & \\
\hline Self-sufficiency & \multirow{8}{*}{$\begin{array}{l}\text { Striving to make a status in } \\
\text { society } \\
\text { Preference to earn and be } \\
\text { financial self-sufficient }\end{array}$} & \multirow[t]{8}{*}{ Women Empowerment } \\
\hline Financial self-sufficiency & & \\
\hline Essence of life & & \\
\hline Feeling of Uselessness & & \\
\hline $\begin{array}{l}\text { Supporting less privileged } \\
\text { women }\end{array}$ & & \\
\hline Society's adversity & & \\
\hline $\begin{array}{c}\text { Women are capable of achiev- } \\
\text { ing }\end{array}$ & & \\
\hline Proving one's abilities & & \\
\hline
\end{tabular}




\begin{tabular}{|c|c|c|}
\hline Consent of male elders & \multirow{8}{*}{$\begin{array}{l}\text { Working in accordance with } \\
\text { social values } \\
\text { Trust concerns } \\
\text { Patriarchy system } \\
\text { Equilibrium between work } \\
\text { and life }\end{array}$} & \multirow[t]{8}{*}{ Gender and context } \\
\hline Parents/husband/In-laws & & \\
\hline Society's acceptance & & \\
\hline Reputable job hunt & & \\
\hline Aligned with society & & \\
\hline Family as first priority & & \\
\hline $\begin{array}{c}\text { Women only considered } \\
\text { homemakers }\end{array}$ & & \\
\hline $\begin{array}{l}\text { Difficult to obtain family's } \\
\text { confidence }\end{array}$ & & \\
\hline Taliban laws & \multirow{8}{*}{$\begin{array}{l}\text { Security concerns/Terrorism } \\
\text { Mistreatment of Religion }\end{array}$} & \multirow{8}{*}{$\begin{array}{l}\text { Religious fanatics' mistreat- } \\
\text { ment in the form of terrosrism }\end{array}$} \\
\hline Issuance of warnings & & \\
\hline Against women development & & \\
\hline $\begin{array}{c}\text { Prohibition of working women } \\
\text { in Islam }\end{array}$ & & \\
\hline Prohibition of business women & & \\
\hline Explosions & & \\
\hline Abductions & & \\
\hline Criticsm on educated women & & \\
\hline $\begin{array}{l}\text { Bribery in Government insti- } \\
\text { tutions }\end{array}$ & \multirow{5}{*}{$\begin{array}{l}\text { Absence of ethics and commit- } \\
\text { ment in Government institu- } \\
\text { tions } \\
\text { Inefficient Government insti- } \\
\text { tutions }\end{array}$} & \multirow[t]{5}{*}{ Institutional corruption } \\
\hline Institutional Inefficiency & & \\
\hline Inconvenient Laws & & \\
\hline Inflexible rules for women & & \\
\hline Obstacles for women & & \\
\hline $\begin{array}{c}\text { Medical/teaching reputable } \\
\text { careers }\end{array}$ & \multirow{6}{*}{$\begin{array}{l}\text { Absence of business training } \\
\text { Insufficiency of resources }\end{array}$} & \multirow{6}{*}{$\begin{array}{l}\text { Women deprive of indepen- } \\
\text { dent resources, education and } \\
\text { primaryunderstandingof laws }\end{array}$} \\
\hline $\begin{array}{l}\text { Business training non-suitable } \\
\text { for women }\end{array}$ & & \\
\hline $\begin{array}{l}\text { Unfamiliarity marketing/ } \\
\text { market }\end{array}$ & & \\
\hline Finanical dependence & & \\
\hline Middle class & & \\
\hline Limitation of resources & & \\
\hline
\end{tabular}




\begin{tabular}{|c|c|c|}
\hline No government assistance & \multirow{7}{*}{$\begin{array}{l}\text { Unfamiliarity with laws and } \\
\text { regulations } \\
\text { No government assistance }\end{array}$} & \multirow[t]{7}{*}{ Complex Rules and regulations } \\
\hline No awareness initiatives & & \\
\hline Unfamiliarity with laws & & \\
\hline Necessity for supervision & & \\
\hline $\begin{array}{l}\text { Necessity to understand SME's } \\
\text { in pakistan }\end{array}$ & & \\
\hline Extensive issues & & \\
\hline $\begin{array}{l}\text { Extensive commercial and } \\
\text { residential zone }\end{array}$ & & \\
\hline Vocational guidance by NGOs & \multirow{6}{*}{$\begin{array}{l}\text { Women centric NGOsencour- } \\
\text { age women empowerment }\end{array}$} & \multirow{6}{*}{$\begin{array}{l}\text { NGO sector's impressive com- } \\
\text { mitment }\end{array}$} \\
\hline Job supply by NGOs & & \\
\hline Rationales & & \\
\hline Obtaining a living & & \\
\hline Realization of self-worth & & \\
\hline $\begin{array}{l}\text { Emotional and financial } \\
\text { assistance }\end{array}$ & & \\
\hline
\end{tabular}

Coding can be simply explained as converting huge data into less meaningful codes, those must relate to the original data and should mean the same. The researcher allocated various codes to the collected data and combined the similar codes in order to form themes (Table 2).

\section{Research Findings}

The research findings show that women entrepreneurs in KP had a strong desire to transform the society for the betterment of women status. They wanted to gain some kind of independence that allows them to work with legitimacy and that was their goal achievement. This idea of the society was the key entrepreneurial enabler for them. As a participant Mrs. A stated

"We are witnessing $21^{\text {st }}$ century in which many developments have taken place for women. They have even reached space. In KP Pakistan, on the other hand, a woman driving a car is still an astonishing sight".

In KP, Pakistan, women life choices are changing in accordance with the changes in life's circumstances such as marriage, childbirth, divorce and more. Women are forced to make their work life choices within a restrained familial and socio-cultural environment. As echoed by Miss B

"On the record, women in KP survive in a constrained environment in forming public 
life and every public institution is men-centric. Even in the case of free enterprise, working men are considered passionate, enduring and innovative in their endeavors; however, women are considered inactive and are also restricted from involvement in such activities. Therefore, women hardly manage to do networking leading to entrepreneurial development which is as a result of constrained environment by patriarchy culture and not women's inability to function properly. In fact, the narration of B's challenges provides an insight that refers to the absence of opportunities for women and their unwillingness to participate in free enterprise due to men-centric environment".

In KP culture being women means that one should only prioritize family. A woman only needs to focus on being a good daughter, good wife and a great mother eventually (Rehman \& Roomi, 2012). These are the only roles that are thought to be appropriate for women. If someone opts for a role other than the mentioned, then there are consequences to it. First one should have the permission of the elder of the family, otherwise such a step is considered outrageous. Women are considered the custodians of family honor. Such conservative beliefs are widespread in this part of Pakistan and they are continuously underpinning daily life choices of individuals but still these belief's, these norms are acting as authoritative guidelines (Institutional theory) for social behavior of the women of KP, Pakistan. In such culture immediate family support matters a lot. Eight of our interviewees had full family support and due to that they were able to nurture their dreams in the best way possible and turned those dreams into realities. Due to family support they were able to overcome the societal issues and challenges they were facing during their entrepreneurial journey. The remaining two interviewees who had issues having family support also suggest a positive outcome to it. They stated that their family negligence made them want to prove themselves to their families and to the society. As Miss. E stated

"I am grateful to my former husband and in-laws for their conduct towards because it allowed me to view my world differently. I am hopeful that my struggle for Pakhtun women will continue. In the start, I faced multiple challenges as a young separated woman working in a male dominant society, but now I am known for my achievements, Challenges are part of life and now I welcome them with confidence. I believe that challenges motivate me. It's a struggle Pakhtun women inherited when born in this neck of the woods".

Rejection made them stronger in a positive way and with time this positivity led to the success, support and likeness of their immediate family. Baugh et al., (2006) acquired proof that gender imbalance functions as a blockage for one's prosperity and improvement. It can interrupt one's chances and preferences or even restrain them. These imbalances can either be explained with the help of institutional theory or feminism theory. Women's constitutional obedience to men (Standpoint Feminism) in KP Pakistan is reflected in the data investigation. As expressed by Mrs. H 
"My husband does not like and support my business. According to his perception, my main purpose of life is to take care of my home and kids".

Pakistani women's lives are limited to homes and they are ruled out from being a part of decision making. Work life choices of women in Pakistan are constructed and reconstructed mostly according to their life circumstances. Even in the most critical situations and decisions, male head of the families are responsible to decide what's best for their women. As told by Miss. E

"I was in my final year when my grandparents decided I should get engaged to a man who was ten years elder to me and a doctor by profession. He was the only son to his parents. My grandparents did ask for my consent, but I was expected to say yes. In Pakhtun society, a girl's parents or grandparents can decide to whom she should get married on the behalf of the girl. They are thought to have more experience and know-how of the society and people thus their decisions are thought to be more reliable. Some families do ask for the girls consent like my family but many do not even think that is necessary. So according to my grand-parents doctors are the best and safest choice for marriage. They are the only ones who can provide bread even in the time of recession..."

Later, It did not work out and she got divorced. Now the same lady is a successful entrepreneur and proud single mother to a daughter.

Another participant Miss. I mentioned,

"I aced all my studies and held position in my school, which made my elders force me to elect medical studies because according to their perception I was too intelligent to select arts. I was forever fond of sketching and baking but I was not permitted to opt for this area. These kinds of pressures are more hurting for a girl especially with her father not by her side".

Considering women inferior and denying their primary rights such as education have been referred to absurd religious teachings in Pakistan (Roomi \& Parrot, 2008). Ahl (2006) argues that it is useful to show differences for example in level of education and how women and men perform gender in their daily interactions. Focusing on both sexes allows us to see how the construction of entrepreneurship impinges on gender, but it is argued that these aspects take on a particular stickiness especially for women (Muhammad, McElwee \& Dana, 2017). However, Islam actually promotes women's development and allows them to seek education, possess property and business, to have political views, have equal importance, honor and respect as men. Proper understanding of women's position needs to be cultivated and strengthened to bring a positive change, which we see the women entrepreneurs managing to promote and reproduce, contrary to the image the Islamic fundamentalists have tried to create. As expressed by another women entrepreneur Mrs. A, 
"In the year 2012, I received threat letter from Taliban (terrorist organization in Pakistan) to cease my Training Center or I would face unfavorable outcomes. They claimed that my academy was against Islamic teachings and disrespected the religion therefore it must be ceased or else they would destroy it themselves (through bomb)".

The status of women has been wrongly fostered through Islam by extremists, thus resulting in a conservative environment. The data analysis shows that the religion "Islam" is not practiced in the right way when it comes to women rights. Within Pakhtun society, cognitive attributes of Islam hold great importance. These attributes distinguish social position and determine the level of one's involvement in religion of Pakhtun society. According to their perception, women battling for their rights, choosing a career, becoming financially sound or working in male environment are not acceptable and not aligned with their religious beliefs. These symbols have social significance in Pakhtun society. Such religious exploitation and terrorism has been acting as a barrier for women entrepreneurs of KP, Pakistan. Data shows enormous amount of courage by KP women who did not get scared of such groups instead they fought against them for their right even when their lives were threatened. Roomi and Parrott (2008) suggested that inorder to improve women condition in an Islamic society and fight religious extremisim, socities need to foster true interpretation of Islam and women in Islam. This is a very serious issue and can be extremely dangerous if not dealt with on time.

Women empowerment is often understood through the oppressing factors that work against women in a society like the work of Carr, Chen and Jhabvala (1996). They presented theoretical approaches for understanding why women are powerless, but there is a lack of research and theoretical debate on how to strengthen and empower such powerless women (Datta \& Gailey, 2012). Kabeer in 1999 argued that women empowerment is the "ability to make choices" (p. 436). The argument was strengthened through three interrelated dimensions such as, resourcefulness, agency, including process, achievements and outcomes (p. 437). This study also shows connection to Kabeer's (1999) research. The interviewees showed determination towards making their own life choices and also inspired other women to do so. As Miss. E stated

"I decided not to avail further financial assistance from my father. I aimed to set example for all single mothers in society. I owned jewelry of 8.5 million $(8,400 \$)$ worth when I got married. My mother in law seized 7 million $(7,000 \$)$ worth of jewelry at the time of wedding in the name of custom, that I could not redeem anymore. After I separated, I sold the remaining 1.5 million (1500\$) and invested in the ladies' gym owned by my aunt".

The inspiration for such determination came from the idea of being financially independent (resourceful), being part of a social change and proving their value 
(Agency, social change) and achieve what was taken from them (Kabeer, 1999). Kabeer (1999) also suggested a qualitative approach for such studies as qualitative data can be informative and rich resource.

As participant Mrs. A expressed,

"My husband never allowed me to do job, due to family restrictions. I always had the passion to be financially self-sufficient. I always desired to work and be more than just a housewife".

Mrs. D echoed almost same views as

"With the exception of family and friends, financial freedom and self-sufficiency was additional reason for working towards my goals".

Another Participant Miss C put it in those words

"My financial conditions got unpleasant after my father passed away. Supporting my family and working towards my dreams is not easy specially with increasing level of inflation in country. However, if a person is determined then one can face many hurdles and storms. I had the same courage inside me. I wanted to do something with my life. I was determined to achieve my dreams no matter what. In our society, those girls whose fathers are no more are regarded as a liability and face discouragements. I wanted to prove that it otherwise..."

Mrs. J explained her stance on women empowerment in the following way,

"My personal belief is that women must be financial self-sufficient and for that they must work besides taking care of their homes. Because I believe in financial stability of women, therefore I wanted to work on it. Education and financial self-sufficiency of women play a vital role in their economic recognition because they boost their self-confidence. It gives women the confidence that they can survive irrespective of people's opinions".

These participants had the courage to make their own choices in life and achieve their goals which seemed impossible to many. Such determination, passion, courage showed by these women encouraged many to opt for this path and prove themselves. Their courage inspired others thus strengthening women and resulted in empowering them.

Several women entrepreneurs also considrered organizational corruption have a very negative role towards their accomplishments. These normative type constraints acted as a strong barrier. This theme was consistent in all interveiws. The interviewees shared their experiences with the PDA (Peshawar Development Authority" and Tax departments of KP, Pakistan and stated that they had a bad experience while dealing with such departments. Most of the time they are asked for bribes and favors. As 
expressed by one of the interviewees Mrs. A,

"The tax department as well caused me problems. Most of the employees working in that department demanded money in return for not creating problems. The society continuously tries to discourage us, creates hurdles for us so that I would stop working, but rather than stopping such challenges motivates me to work harder with more courage and passion”.

Such behavior creates hurdles for women during their entrepreneurial journey. As individuals belonging to such institutes have power which they can use against those who do not comply. This issue also shows that incompetency of the government to deal with such individuals working in these depatments who thinks they are above the law. In addition to this these departments are not efficient in their work. $80 \%$ of the interviewee stated that they started their entrepreneurial journey from their homes, residential area and they were never told that its not allowed according to the law. PDA (Peshawar Development Authority) after years came in action and started closing down such businesses which affected women entrepreneurs a great deal. They lost their customers and faced serious trouble with their business. They argued that had PDA taken action on this situation from the start, on time, then they would not have faced such trouble. Furthermore their timely action would have acted as a lesson for them. The rules and regulations are complicated and the analysis showed that women lacks basic awareness about them. Hearn (2011) argues men are part of top management in organizations, businesses and government. In this sense, government and policy institutions are part of both the problem and the solutions. Here, we see the entrepreneurs facing a policy problem, which is that the women entrepreneurs are not allowed to work from a residential area instead they are being forced to work in a commercial area. The government is aware that the conservative culture of that area does not allow that and if these women entrepreneurs argue for moving they might face problems from family or the their social circle. Such policies are helping men entrepreneurs but aren't feasible for women entrepreneurs. Given the economic and social conditions of Pakistan, encouraging entrepreneurship can result in development. Still the gendered policy is making it hard for the entrepreneurs. We argue that policy that is considered gender neutral is not, it's also gendered, made by men in the top management.

An additional repeating theme of data revealed that $\mathrm{NGOs}$ operating in $\mathrm{KP}$ are strongly dedicated to entreprenurship. $70 \%$ of the interviewees praise NGO sector and even categorized their performance above what the government is doing here for women social entrepreneurs. The interviewees expressed their gratitude and expressed that they found NGOs extremely cooperative who helped them learn a lot. 
The women empowerment NGO sector is constantly creating awareness and helping women in startups.

\section{Dissertation of Findings}

Women entrepreneurship is a growing field research. Particularly, the influence of institutional context and gender roles is rapidly advancing in the literature thus resulting in a solid foundation for debate. The outcomes discussed in the paper evidently illustrates the role of institutional and feminism theory in accounting for structuring society for women entrepreneurship experience. It also suggests the usefulness of a unified framework of two theories which best explains women social entrepreneurship. Enabling factors such as self efficacy, finanicial independance, women empowerment and the drive towards changing womens position in the society were found to be nested in their contours of life. The researcher was able to isolate such opportunities and constraints, thus highlighting the complex interweaving women entrepreneurship involvement in this specific scenario. Findings emphasize on the effectiveness of acknoweldging context, an integrated interdependent system focusing on the role of different determinants in shaping social entrepreneurship. It highlights the most influential formal and informal obstacles refraining women entrepreneurship in this context leading to their current involvement in entrepreneurial activities. Furthermore it suggests the effectiveness of institutional and feminism theory as most appropriate theoretical monocle in entrepreneurship research. The researcher was able to study and explore the conceptions namely, role rivalry, gender, gender imbalance and feminism through these two theories. It was observed that irrespective of the challenges and obstacles implemented by society, entrepreneurs managed to continue their struggle and bring a positive change in KP's society. The findings suggest that instead of letting the society structure their life, the entrepreneurs were determined to structure society according to their needs, thus resulting in working passionately about women empowerment and betterment of the society. These findings support previous work of research on entrepreneurship and recommend the effectiveness of multi-layered research method (Gimenez \& Calabro, 2017).

The plausible uniqueness of our findings is shown in the way the researcher has apprehended interpretive cases of women social entrepreneurs under institutional and feminism theory. The two theories developed understanding of gender and presented insight by integrating indicators from the mentioned theories. This integration also contributes to the whole new insights about social entrepreneurship theory and practice, thus resulting in shedding new light on women entrepreneurial research. The antecedent work of research suggests that there is requirement for further investigation in this context. Moreover, it particularizes the entrepreneurship 
involvement in developing country context, more specifically Muslim countries. The strong salience of institutional pressures, contemplating the preference of gendered worth's and patriarchy culture which is deeply permeated in the KP, Pakistan culture, thus influencing the experiences and expressions of women social entrepreneurship in that context.

\section{Conclusion and Future Research Directions}

Responding to the recent calls in the literature this study developed a unique understanding of cultural influence of gender and women's participation and expectancy in case of a developing country, both theoretically and empirically. The study focused on the interpretative cases of women social entrepreneurs in a dynamic integration of institutional and feminism theories to understand the influence of gender; hence, augmenting logic by integrating prognoses of the mentioned theories. Moreover, it also highlights a distinct role of entrepreneurship that is, questioning the existing social norms and orders. Findings of this study recommend that this pattern of entrepreneurship is unique because its purpose is to create social benefits.

In light of the narratives presented, it is clear that women's entrepreneurial choices are determined by the gendered socio-cultural structures of their society. Consistent with the study of Jennings and Brush (2013) a women entrepreneur's capacity to exercise agency is largely dependent on family system. In this respect, the institution of family is an important indicator in explaining women entrepreneurial activity in this context. However, there is evidence that things are beginning to change in Pakistan with better educational advancement and a gradual change in the mind set of families and society. In addition, more support from husbands and in-laws help reduce the burden of domestic chores for women entrepreneurs. Although some women still report dissatisfaction with the cultural norms and practices that hinder their entrepreneurial potential, but we argue that the fact they are able to work and help other women around them does represent the gradual change. It is very moderate, but it is still a positive change, and through empowering other women, they are starting this cycle of change kind of a ripple effect. This highlights the agency in the entrepreneurial process, which enabled them to work around the barriers. Future research can focus on how the women who face up to these barriers are gradually eroding the extent to which they are entrepreneurial obstacles. Furthermore, we found that women entrepreneurial choices were very much embedded in culture and norms and the legitimacy associated with that. While our findings support the extant literature, our core contribution lies in the interpretive accounts and how they have captured the dynamic interviewing of gendered socio-cultural influences on women entrepreneurship activity in KP. We argue that entrepreneurship proved to 
be emancipating for these women. It awakened their sense of identifying their worth and strengthened their self-confidence towards bringing a change. It was monitored that irrespective of the continual constraints by society and rigid environment, the entrepreneurs managed to work on their goals to bring a positive change in KP's society. In future, researchers can attempt to study the challenges of entrepreneurs and how they tackle them to ensure their endurance in an incompatible environment. Researchers could also study distinct counteractions of entrepreneurs regarding context-based opportunities and challenges, and their approach for tackling them. This way, it will provide a broader perspective of entrepreneurial behavior. Therefore, conclusion of the study is that institutions and gendering of the institutions are key components in forming women social enterprise in case of KP region of Pakistan. Moreover, it also suggests that integration of institution and gendering present an appropriate groundwork for a constructive general theory explaining women social enterprise in the context of developing countries. Subsequently, this study presents a unique understanding of women entrepreneurs and their experiences in KP. It also discovered institutional challenges and incentives. Nonetheless, it is also crucial to highlight limitations of the study. As this study adopted a qualitative approach of research with a non-probability sample, therefore, it is deficient in exterior validity. As a result, outcomes of this research lack generalizability in other situations. Moreover, it is challenging to approach women entrepreneurs, and manage to interview them because of social and cultural restrictions.

\section{References}

Al-Dajani, H., Carter, S., Shaw, E., \& Marlow, S. (2015). Entrepreneurship among the displaced and dispossessed: Exploring the limits of emancipatory entrepreneuring. British Journal of Management, 26(4), 713-730.

Ahl, H. (2006). Why research on women entrepreneurs needs new directions. Entrepreneurship Theory and Practice, 30(5), 595-621.

Anderson, A. R., Younis, S., Hashim, H., \& Air, C. (2019). Social enterprising informing our concept; exploring informal micro social enterprise. Social Enterprise Journal, 15(1), 94-110.

Amable, B. (2003). The diversity of modern capitalism. New York, NY: Oxford University Press.

Attride-Stirling, J. (2001). Thematic networks: An analytic tool for qualitative research. Qualitative Research, 1(3), 385-405.

Baughn, C. C., Chua, B. L., \& Neupert, K. E. (2006). The normative context for women's participation in entrepreneurship: A multicountry study. Entrepreneurship Theory and Practice, 30(5), 687-708.

Berg, M. J. (1997). Status of research on gender differences: The gender framework for health research affects much of the information given by the pharmacist delivering pharmaceutical care. Journal of 
the American Pharmaceutical Association, 37(1), 43-56.

Brush, C. G., \& Vanderwerf, P. A. (1992). A comparison of methods and sources for obtaining estimates of new venture performance. Journal of Business Venturing, 7(2), 157-170.

Bruton, G. D., Ahlstrom, D., \& Li, H. L. (2010). Institutional theory and entrepreneurship: Where are we now and where do we need to move in the future? Entrepreneurship Theory and Practice, 34(3), 421-440.

Bukhari, A. H. S., Gaho, G. M., \& Soomro, K. H. (2019). Gender inequality: Problems \& its solutions in Pakistan. The Government-Annual Research Journal of Political Science, 7(7), 47-58.

Carr, M., Chen, M., \& Jhabvala, R. (1996). Speaking out: Women's economic empowerment in South Asia. New Delhi: Vistaar Publications.

Creswell, J. W., Hanson, W. E., Clark Plano, V. L., \& Morales, A. (2007). Qualitative research designs: Selection and implementation. The Counseling Psychologist, 35(2), 236-264.

Datta, P. B., \& Gailey, R. (2012). Empowering women through social entrepreneurship: Case study of a women's cooperative in India. Entrepreneurship Theory and Practice, 36(3), 569-587.

Economic Advisor's Wing, Finance Division, Government of Pakistan. (2016). Pakistan Economic Survey 2016-17. Retrieved from http://www.finance.gov.pk/survey/chapters_17/Pakistan_ES_2016_17_ pdf.pdf

Ettl, K., \& Welter, F. (2010). Gender, context and entrepreneurial learning. International Journal of Gender and Entrepreneurship, 2(2), 108-129.

Fine, L. E. (2017). Gender and sexual minorities' practice and embodiment of authentic leadership: Challenges and opportunities. Advances in Developing Human Resources, 19(4), 378-392.

Foss, L., Henry, C., Ahl, H., \& Mikalsen, G. H. (2018). Women's entrepreneurship policy research: A 30-year review of the evidence. Small Business Economics, 53(2), 409-429.

Giménez, D., \& Calabrò, A. (2017). The salient role of institutions in Women's entrepreneurship: A critical review and agenda for future research. International Entrepreneurship and Management Journal, 14(4), $857-882$.

Hearn, J. (2011). Men/Masculinities: War/Militarism-searching (for) the obvious connections? In A. Kronsell \& E. Svedberg (Eds.), Making gender, making war: Violence, military and peacekeeping practices. (pp. 49-62). New York, NY: Routledge.

Henry, C., Foss, L., Fayolle, A., Walker, E., \& Duffy, S. (2015). Entrepreneurial leadership and gender: Exploring theory and practice in global contexts. Journal of Small Business Management, 53(3), 581-586.

Henry, C., Foss, L., \& Ahl, H. (2016). Gender and entrepreneurship research: A review of methodological approaches. International Small Business Journal, 34(3), 217-241.

Hanson, L. (1992). Feminist jurisprudence in a conventional context: Is there room for feminism in 
Dworkin's theory of interpretive concepts? Osgoode Hall Law Journal, 30(2), 355-373.

Hurley, A. E. (1999). Incorporating feminist theories into sociological theories of entrepreneurship. Women in Management Review, 14(2), 54-62.

Jennings, J. E., \& Brush, C. G. (2013). Research on women entrepreneurs: Challenges to (and from) the broader entrepreneurship literature? The Academy of Management Annals, 7(1), 663-715.

Kabeer, N. (1999). Resources, agency, achievements: Reflections on the measurement of women's empowerment. Development and change, 30(3), 435-464.

Knight, M. (2016). Race-ing, classing and gendering racialized women's participation in entrepreneurship. Gender, Work E Organization, 23(3), 310-327.

Lent, M., Anderson, A., Yunis, M. S., \& Hashim, H. (2019). Understanding how legitimacy is acquired among informal home-based Pakistani small businesses. International Entrepreneurship and Management Journal, 15(2), 341-361.

Mason, C., Kirkbride, J., \& Bryde, D. (2007). From stakeholders to institutions: The changing face of social enterprise governance theory. Management Decision, 45(2), 284-301.

McElwee, G., \& Al-Riyami, R. (2003). Women entrepreneurs in Oman: Some barriers to success. Career Development International, 8(7), 339-346.

McMullen, J. S., \& Warnick, B. J. (2015). Article commentary: To nurture or groom? the parent-founder succession dilemma. Entrepreneurship Theory and Practice, 39(6), 1379-1412.

Muhammad, N., McElwee, G., \& Dana, L. P. (2017). Barriers to the development and progress of entrepreneurship in rural Pakistan. International Journal of Entrepreneurial Behavior E⿱ Research, 23(2), 279-295

North, D. C. (1990). Institutions and a transaction-cost theory of exchange. In J. E. Alt \& K. A. Shepsle (Eds.), Perspectives on positive political economy. (pp. 182-194). New York, NY: Cambridge University Press.

Pakeeza, S. (2015). Domestic violence laws and practices in Pakistan. VFAST Transactions on Education and Social Sciences, 6(1), 17-20.

Panda, S. (2018). Constraints faced by women entrepreneurs in developing countries: Review and ranking. Gender in Management: An International Journal, 33(4), 315-331.

Parvin, L., Rahman, M. W., \& Jia, J. (2012). Determinates of women micro-entrepreneurship development: An empirical investigation in rural Bangladesh. International Journal of Economics and Finance, 4(5), 254-260.

Pratt, D. (2010). Religion and terrorism: Christian fundamentalism and extremism. Terrorism and Political Violence, 22(3), 438-456.

Rehman, S., \& Roomi, M. A. (2012). Gender and work-life balance: A phenomenological study of wom- 
en entrepreneurs in Pakistan. Journal of Small Business and Enterprise Development, 19(2), 209-228.

Roomi, M. A., \& Harrison, P. (2010). Behind the veil: Women's capacity building and enterprise development in Pakistan. International Journal of Gender and Entrepreneurship, 2(2), 150-172.

Roomi, M. A., \& Parrott, G. (2008). Barriers to development and progression of women entrepreneurs in Pakistan. The Journal of Entrepreneurship, 17(1), 59-72.

Roomi, M. A., Rehman, S., \& Henry, C. (2018). Exploring the normative context for women's entrepreneurship in Pakistan: A critical analysis. International Journal of Gender and Entrepreneurship, 10(2), 158-180.

Sambharya, R., \& Musteen, M. (2014). Institutional environment and entrepreneurship: An empirical study across countries. Journal of International Entrepreneurship, 12(4), 314-330.

Scott, W. R. (2008). Institutions and organizations: Ideas and interests. Thousand Oaks, CA: Sage Publications.

Stead, V. (2017). Belonging and women entrepreneurs: Women's navigation of gendered assumptions in entrepreneurial practice. International Small Business Journal, 35(1), 61-77.

Silverman, D., \& Marvasti, A. (2008). Doing qualitative research: A comprehensive guide. Thousand Oaks, CA: Sage Publications.

Welter, F., \& Smallbone, D. (2011). Institutional perspectives on entrepreneurial behavior in challenging environments. Journal of Small Business Management, 49(1), 107-125.

Yunis, M. S., Hashim, H., \& Anderson, A. R. (2019). Enablers and constraints of female entrepreneurship in Khyber Pukhtunkhawa, Pakistan: Institutional and feminist perspectives. Sustainability, 11(1), 1-20. https://doi.org/10.3390/su11010027

Zahra, S. A., \& Wright, M. (2016). Understanding the social role of entrepreneurship. Journal of Management Studies, 53(4), 610-629.

Zaman, R. M., Stewart, S. M., \& Zaman, T. R. (2006). Pakistan: Culture, community, and filial obligations in a Muslim society. In J. Georgas, J. W. Berry, F. J. R. van de Vijver, Ç. Kağıtçıbaşı \& Y. H. Poortinga (Eds.), Families across cultures: A 30 nation psychological study. (pp. 427-434). New York, NY: Cambridge University Press. 